\title{
Srovnání obsahu vybraných kurikulárních dokumentů tělesné výchovy pro primární vzdělávání v Irsku, Nizozemsku a České republice
}

\author{
Martina Habrdlová, Michal Lupač, Petr Vlček
}

Masarykova univerzita, Pedagogická fakulta, Katedra tělesné výchovy a výchovy ke zdraví

Redakci zasláno 15. 11. 2016 / upravená verze obdržena 31. 8. 2017 /

k uveřejnění přijato 4. 9. 2017

\begin{abstract}
Abstrakt: Studie se zabývá komparací současných kurikulárních dokumentů (zejména vzdělávacích programů) tělesné výchovy pro primární vzdělávání v České republice, Irsku a Nizozemsku. Studie nejprve uvádí čtenáře do širšího kontextu řešené problematiky. Následuje přehledová kapitola, ve které jsou specifikovány výzkumné cíle. Na tomto podkladě je dále popsána metodika srovnávání kurikulárních dokumentů. Následující část nabízí klíčové výsledky provedeného šetření, které byly interpretovány z pohledu revizí kurikula v České republice. Za zásadní pokládají autoři skutečnost, že české kurikulum nemá dostatečně provázané vzdělávací cíle a vzdělávací obsah a dále že cíle tělesné výchovy nejsou srozumitelně definované. Na základě těchto zjištění jsou nastíněna doporučení pro příští revize rámcových vzdělávacích programů.
\end{abstract}

Klíčová slova: kurikulum, kurikulární dokumenty, vzdělávací programy, tělesná výchova, srovnání, komparace, Irsko, Nizozemsko, Česká republika

Tento text vznikl z potřeby reflektovat stav českého koncepčního, a zejména projektovaného kurikula², obecně vnímaný jako nevyhovující (viz např. Dvořák, Starý, \& Urbánek, 2015; Janík, 2013; Janík et al., 2010; Kuhn, 2011 aj.). Dle Šípa (2014) je onen stav výsledkem kurikulárního reformování, v jehož počátku nebyla nedostatečnost původního kurikula přijatelně zdůvodněna. Ztotožňujeme se s názorem, že reformní úsilí bývají realizována, aniž by se poučila z nedostatků či předností výchozích podmínek (srov. Kuřina, 2014). Tento fakt může stát za nepřesvědčivými výsledky

1 Př́spěvek vznikl s podporou projektu specifického výzkumu MUNI/A/0963/2015 Výzkum kurikula vzdělávací oblasti Člověk a zdraví realizovaného na Pedagogické fakultě Masarykovy univerzity v Brně.

2 V textu budeme vycházet $\mathrm{z}$ forem existence kurikula podle Maňáka a Janíka (2009). Soustředíme se na vzdělávací dokumenty jednotlivých států, zejména na vzdělávací programy. 
kurikulární reformy a nepřijetím některých změn, které nebyly dostatečně diskutovány s odbornou veřejností či pedagogickými pracovníky.

Také autoři předloženého textu (vycházejíce z již publikovaných prací: Janík, 2013; Janík, Najvar, \& Solnička, 2011; Vlček \& Mužík, 2012 aj.) pocitovali určité nejasnosti v tom, které konkrétní skutečnosti se jeví jako palčivé v souvislosti s rámcovými vzdělávacími programy (RVP), především pak s tělesnou výchovou (TV), na kterou soustředíme pozornost v tomto př́spěvku. Aby bylo možno pozorovat postupný vývoj našeho uvažování v této záležitosti, uvádíme předložený text přehledovou kapitolou o relevantních výzkumech. Studium těchto pramenů nám umožnilo postihnout některé obtíže, kterými je česká TV zatížena.

V tomto textu zamýšlíme srovnávat kurikulární dokumenty TV pro primární vzdělávání v Irsku, Nizozemsku a České republice. Máme za to, že budeme-li problémy českého kurikula nazírat z komparativní perspektivy, přispějeme k smysluplnému a výzkumem podloženému hledání strategií, jež mohou vést $\mathrm{k}$ příznivé změně ve vztahu k revizím RVP či např́íklad k implementaci nedávno zveřejněných standardů TV (srov. Průcha, 2015; Walterová, 2006 aj.).

\section{K vybraným výzkumům v řešené problematice a stanovení výzkumných cílů}

Vzhledem k omezenému rozsahu příspěvku jsme se do přehledu studií rozhodli zařadit texty, které odpovídaly poměrně úzce zvoleným kritériím, a které proto byly pro nás relevantní. Zvolenými kritérii bylo zaměření prací na kurikulum TV, alespoň částečná orientace na primární vzdělávání, publikování výzkumů v uplynulé dekádě a dostatek informací o použité metodologii výzkumu.

Autoři Zhu, Ennis a Chen (2011) hledali odpověd’ na otázku, do jaké míry je TV projektovaná ve vzdělávacích programech realizovaná ve školní praxi jedné konkrétní školy v USA. K analýze pozorování výukových jednotek TV a rozhovorů s učitelem a žáky bylo použito konstantní srovnávání (otevřené a axiální kódování). Výzkum ukázal, že míru propojení obou forem kurikula ovlivňují především kontextuální faktory konkrétní školy a také preference a hodnotový systém učitele. K podobným závěrům dospěl Jin (2013), který vyšetřoval postoje učitelů $\mathrm{k}$ reformě kurikula TV. Prostřednictvím analýzy dokumentů mimo jiné zjistil rozpory mezi kurikulem projektovaným 
a realizovaným. Annerstedt (2008) srovnal projektované kurikulum TV skandinávských států. Jako výzkumnou metodu použil kvalitativní analýzu textů, a to jak kurikulárních dokumentů, tak také analýzu výzkumů tělesné výchovy z let 1998-2008. Tímto způsobem autor mimo jiné odhalil nedostatečný soulad mezi zamýšleným a realizovaným kurikulem. Rossi a kol. (2009) pomocí diskurzivní analýzy zkoumali realizovatelnost australského projektovaného kurikula $\mathrm{v}$ závislosti na rétorice $\mathrm{v}$ něm obsažené a míre porozumění textu učiteli. Autoři mimo jiné poukázali na nekonzistenci zamýšlených významů kurikula a jejich chápání a realizaci ve školní praxi. Komparativní studii švédského a jihoafrického dosaženého kurikula uskutečnil Kougioumtzis (2014). Autor uvažoval kongruenci koncepcí napříč různými formami kurikula TV a dospěl například k závěru, že ve Švédsku se projektované kurikulum orientuje na podporu zdraví, zatímco dosažené je spojené se sportovní koncepcí.

Všechny $\mathrm{z}$ výše zmíněných studií $\mathrm{v}$ závěrech odkazují na fakt, že $\mathrm{v}$ případě provázání všech forem kurikula dosahují žáci lepších studijních výsledků (srov. Squires, 2012). Proto (podobně jako u citovaných autorů) nás provedená rešerše přiměla zaměřit cíle naší studie na strukturu kurikulárních dokumentů a konzistenci kurikula jako jednu z podstatných kvalit pro jeho účinné fungování.

\subsection{Výzkumný cíl}

Cílem studie je analyzovat vybrané současné kurikulární dokumenty (zejména vzdělávací programy) pro primární vzdělávání (vzdělávání na úrovni ISCED 1 dle mezinárodní klasifikace; podle Průchy et al., 2001, s. 179) v Irsku, Nizozemsku a České republice a porovnat přístupy k projektování tělesné výchovy ve vybraných státních celcích. Výběr států pro účel této studie vycházel z Naulova modelu $(2003,2011)$, který pracuje se čtyřmi hlavními směry koncepce TV v Evropě - zdravotní (ČR), pohybově-dovednostní (Nizozemsko), sportovní (Irsko) a zdatnostní. Připouštíme, že v ideálním případě by bylo vhodné do naší komparativní studie zařadit minimálně ještě jeden prototypický model kurikula tělesné výchovy.

Při volbě států nás dále motivovaly jednak odlišnosti, které jsou pro porovnávané státní útvary typické (různé historické a kulturní tradice, státní zř́zení, ekonomický rozvoj, jazyk, geografické ukazatele aj.), ale zároveň oblasti, ve kterých se sledované státy shodují. V neposlední řadě hrála významnou roli také naše jazyková vybavenost a osobní zkušenost se školstvím v dané zemii a rovněž menší pozornost česky píšících autorů věnujících se vybraným státům. 


\section{Metodika}

$\mathrm{V}$ rámci srovnávací analýzy použijeme řadu technik, které podrobněji popíšeme v dalších odstavcích. Budeme se přitom držet Beredayova (1964) čtyřstupňového modelu. Protože autorova metoda je orientována poněkud obecněji ${ }^{3}$ než tato studie, přizpůsobíme jednotlivé kroky tak, aby bylo možné metodu aplikovat při srovnávání dokumentů.

\section{A. Popis (deskripce)}

Základní soubor pro výzkum projektované formy kurikula tělesné výchovy irského školství tvoří následující kurikulární dokument:

- Physical Education Primary School Curriculum (National Council for Curriculum and Assessment, 1999a).

Fakta, která jsme získali analýzou kurikulárního dokumentu, jsme v prezentované studii doplnili informacemi z metodického průvodce pro učitele, který je oficiálně doporučovaným doplňujícím metodickým materiálem ke kurikulárnímu dokumentu:

- Physical Education Teacher Guidelines (National Council for Curriculum and Assessment, 1999b).

Analyzovanými nizozemskými dokumenty jsou:

- Kerndoelen Primair Onderwijs - Klíčové cíle pro primární a nižší sekundární vzdělávání (National Institute for Curriculum Development, 2006), pro přehlednost dále v textu označován jako Klíčové cíle;

- Basis dokument Bewegingsonderwijsvoorhet Basisonderwijs - Základní dokument TV pro základní vzdělávání (National Institute for Curriculum Development, 2011), pro přehlednost dále v textu označován jako Základní dokument.

Analyzovanými českými dokumenty jsou:

- Rámcový vzdělávací program pro základní vzdělávání (MŠMT, 2016);

- Standardy pro základní vzdělávání: Tělesná výchova (zdravotní tělesná výchova) (MŠMT, 2013).

3 Autor se zaměřuje na srovnání vzdělávacích fenoménů dvou a více států. 
V této fázi výzkumu jsme využili jako dílčí analytickou proceduru otevřené kódování (viz Glaser, 2004; Glaser \& Strauss, 1967; Strauss \& Corbinová, 1999). Text byl „roztř́šš̌n“ do kategorií a jejich charakteristik (srov. Glaser, 2004). Takto vzniklým textovým fragmentům byly přiděleny názvy (kódy, viz Švaříček \& Šed'ová et al., 2007, s. 211). Důležitost jednotlivých kódů se vynořila z textu (srov. Glaser, 2004). Dlužno však dodat, že jsme do výzkumu vstupovali s jistými tématy přejatými od jiných autorů (Vlček \& Janík, 2010), kombinovány tedy byly deduktivní a induktivní postupy. Vzniklý kategoriální systém jsme podrobili předvýzkumnému šetření s cílem zjištění jeho reliability. Pro ověření spolehlivosti výzkumného nástroje jsme využili duplicitní kódování, které bylo provedeno na RVP ZV. Současně jsme si vědomi mezí analýzy zkoumaných dokumentů. Těmi jsou především jazyková bariéra při překladu nizozemského dokumentu a nemožnost setkání s autory dokumentů, které by napomohlo hlubšímu pochopení kontextu, ve kterém dokumenty existují.

\section{B. Porozumění (interpretace)}

Jak ukazuje Bereday (1964, s. 20), existuje nekonečné množství vzájemných vztahů mezi sledovaným jevem (v našem případě kurikulárními dokumenty) a společností. Autor proto věnuje ve fázi interpretace pozornost kontextuálním faktorům (např. historickým, politickým, ekonomickým či sociálním). My pozornost směřujeme na kurikulární dokumenty, proto se v tomto kroku zaměřujeme především na interpretaci psaného textu, který jsme analyzovali. Otázce kontextuality se věnujeme v dřívějších pracích (Habrdlová, 2014; Lupač, 2016).

\section{Juxtapozice}

Juxtapozice je postavení jednotlivých charakteristik sledovaných států vedle sebe (Walterová, 2006, s. 98; Vlček \& Janík, 2010, s. 67). V této fázi je třeba věnovat pečlivou pozornost ustanovení tertia comparationis - východiska našeho srovnání, které bude podstatou výsledné smysluplné interpretace výsledků (Bereday, 1964, s. 9-10; Manzon, 2007, s. 117). Holmes (1981, zvláště s. 111-114) hovoří o ideálně typických vzorech, které je třeba stanovit, aby

\footnotetext{
Při induktivním myšlenkovém postupu vyvozujeme obecný závěr na základě poznatků o jednotlivostech (Vlček, 2015, s. 11); indukce nás postupně vede ke zrodu teorie - ke stanovení tertia comparationis - konstant či univerzálií, jež jsou současně kritérii srovnatelnosti všech států. Oproti tomu při deduktivním postupu je tertium comparationis převzato z jiného výzkumu a rozpracováno ve formě systému kategorií a dále konkretizováno ve srovnávaných objektech (tamtéž).
} 
bylo možné komparaci provést. My tyto „ideální typy“ do výzkumu vnášíme v podobě kategorií, které budou nástrojem pro analýzu kurikula.

\section{Vlastní srovnání}

V tomto kroku provedeme souběžné srovnání zpracovaných charakteristik sledovaných států. Podle Walterové (2006; srov. Bereday, 1964) nastává srovnání tehdy, když porovnávané fenomény vztáhneme k nadřazenému pojmu nebo hodnotě. Touto hodnotou nám bylo tertium comparationis ustanovené v předchozím kroku. U srovnávaných fenoménů se takto eliminuje vše, co je z hlediska cíle komparace nepodstatné (Holmes, 1981).

\section{Výsledky}

Následující podkapitola si klade za cíl seznámit čtenáře s výsledky našeho srovnávacího výzkumu. Uvědomujeme si, že vyčerpávající prezentace analýz všech studovaných dokumentů není vzhledem k omezenému rozsahu předloženého textu možná. Zájemce o hlubší analýzu dokumentů proto odkazujeme na dřívější práce autorů (Habrdlová, 2015; Lupač, 2016).

\subsection{Komparace formálních charakteristik dokumentů}

Jsme si vědomi, že v Nizozemsku probíhá intenzivní diskuse týkající se nového kurikulárního dokumentu Onderwijs2032 (Horváthová, 2015; OCW, 2016). Výběr nizozemských dokumentů pro analýzu byl však ovlivněn jejich současnou aktuálností a rovněž dobou, ve které byly dokumenty zkoumány (shromažd’ování informací o nizozemském kurikulu probíhá již od r. 2013). Vzhledem k problematické dostupnosti informací o novém rozpracovaném dokumentu jsme se rozhodli pro analýzu dokumentů, které jsou v současnosti v Nizozemsku platné.

Nizozemský závazný dokument Klíčové cíle má celkem 73 stran. Vzdělávací oblast Tělesná výchova zaujímá v dokumentu šest stran a kromě charakteristiky oblasti zahrnuje pouze dva klíčové cíle: Cíl 57 - Žáci se naučí zodpovědným způsobem účastnit celoživotní pohybové aktivity (bewegingscultuur), která nás obklopuje, a naučí se hlavním principům nejdůležitějších sportů a forem cvičení; Cíl 58 - Žáci se naučí účastnit pohybových aktivit s ostatními žáky, a to s respektem, v souladu s domluvenými pravidly a s přihlédnutím k vlastním pohybovým možnostem. Tyto cíle nejsou nijak dále strukturovány. Protože klíčové cíle pro TV začínají vazbou „Žáci se naučí, můžeme část dokumentu určenou pro TV označit za orientovanou na žáka (outcome 
based). Závazný dokument byl v naší analýze doplněn informacemi získanými ze Základního dokumentu, který však není závazný. Základní dokument je oproti Klíčovým cílům, popsaným výše, mnohem obsáhlejší (432 stran) a jinak strukturovaný.

V Irsku je tělesná výchova pro primární vzdělávání projektována v samostatném dokumentu o více než 80 stranách formátu A4. Několik klíčových cílů tělesné výchovy, které jsou formulovány $\mathrm{v}$ úvodu, je dále rozpracováno do podoby cílů specifických. Učivo se člení do čtyř úrovní pro přípravné ročníky, 1. a 2., 3. a 4., a 5. a 6. ročník. Vzdělávací obsah je pro každou jednotlivou úroveň uspořádán do tematických linií (strands), ty dále do učebních oblastí (strand units). V každé oblasti jsou formulovány výstupy, které by měl být žák v dané úrovni vzdělávání schopen uskutečnit. Projektované kurikulum je tedy, podobně jako nizozemský systém dokumentů, orientováno na výstupy na straně žáka (outcome based).

Všechny úrovně primárního vzdělávání zmiňují přímo v dokumentu mezioborové souvislosti (integration) a též vazby v rámci předmětu tělesná výchova (linkage; např. „Atletika zahrnuje činnosti, které jsou vhodné také pro vývoj dovedností v gymnastice a hrách," NCCA, 1999a, s. 16). Dále jsou v dokumentu popsány způsoby hodnocení vzdělávacích výsledků v tělesné výchově. Doporučeno je hodnocení formativního charakteru, které se má vztahovat $\mathrm{k}$ definovaným cílům.

Český Rámcový vzdělávací program pro základní vzdělávání má 164 stran formátu A4. Vzdělávací obor Tělesná výchova je spolu s vzdělávacím oborem Výchova ke zdraví v dokumentu začleněn do vzdělávací oblasti Člověk a zdraví. Tu tvoří úvodní dvoustránkový text, který charakterizuje vzdělávací oblast a formuluje její cíle. Vzdělávací obsah je závazně vymezen v podobě očekávaných výstupů, které jsou v rámci primárního vzdělávání rozčleněny pro 1. a 2. období, a učiva, které si mají žáci osvojit. Také český dokument je tedy formulován $v$ jazyce činností a způsobilosti žáka. Učivo je rozděleno do linií, které procházejí dokumentem v několika ročnících. Celkově je vzdělávací oblasti Člověk a zdraví věnováno 12 stran z celého dokumentu. $\mathrm{Z}$ toho je 7 stran věnováno TV vyváženě na úrovních primárního a nižšího sekundárního vzdělávání. Druhým českým dokumentem, který jsme v naší práci podrobili analýze, jsou Standardy pro základní vzdělávání: Tělesná výchova (zdravotní tělesná výchova). Dokument má celkem 33 stran, z nichž 13 je věnováno 1. stupni. Standardy nemají závazný charakter. Jsou zpracovány 
v tabulkách, které jednotlivě přísluší každému očekávanému výstupu z RVP ZV. Tyto tabulky jsou vytvořeny podle stejného systému např́ič všemi vzdělávacími oblastmi a uvádějí vzdělávací obor, ročník, tematický okruh, očekávaný výstup z RVP, ke kterému se konkrétní tabulka vztahuje, dále indikátory a několik ilustrativních úloh s poznámkami $\mathrm{k}$ daným úlohám.

Formální charakteristiky jednotlivých dokumentů přehledně uvádíme níže (tabulka 1).

\subsection{Komparace obsahu kurikulárních dokumentů}

V následujících odstavcích popisujeme jednotlivé oblasti zkoumaných dokumentů v deduktivně přejatých a induktivně „vynořených“ kategoriích, což nám umožnilo nejen komparaci kurikulárních dokumentů, ale současně i pozorovat, zda jsou v dokumentech provázány vzdělávací cíle a vzdělávací obsah; v případě českého dokumentu též klíčové kompetence. Sledovali jsme tedy, zda jsou dokumenty kongruentní. Jak jsme uvedli, kategoriální systém byl pro tento účel převzat od autorů Richterové (2006) a Vlčka a Janíka (2010). Induktivními kategoriemi jsou: Učení na základě vzájemné spolupráce, Aspekty bezpečnosti v kurikulu tělesné výchovy, Extrakurikulární pohybové aktivity, Zohlednění aspektů kultury a národního vědomí v kurikulu tělesné výchovy, Význam životního prostředí v kurikulu tělesné výchovy.

\section{Orientace na rozvoj osobnosti a sociální vztahy}

Identifikace oblasti ve všech sledovaných dokumentech napovídá, že je tělesné výchově ve všech státech přisuzován velký vliv na celkový rozvoj žáka. Irský dokument formuluje pro tuto oblast několik specifických cílů. Ve vztahu k vlastní osobě má tělesná výchova rozvíjet sebeúctu, sebeuvědomění, iniciativu. V oblasti mezilidských vztahů se žáci mají učit důvěře, citlivé komunikaci a spolupráci s ostatními. V obsahu tohoto dokumentu jsou sociální a osobnostní aspekty pojaty např. jako hry založené na důvěře k ostatním (trust activities). ${ }^{5}$ Např́ć všemi úrovněmi kurikula je zdůrazněna skupinová diskuze k problematice (např. diskutovat vliv rozběhu na délku skoku dalekého), také přijetí úspěchu i neúspěchu a stanovování osobních výzev. Žáci mají být vedeni ke schopnosti hodnotit partnerovu originalitu. Pozornost má být také věnována podpoře a asistenci partnera při některých (např. gymnastických) cvičeních.

5 Př́́klad: Žák se zavázanýma očima následuje za pomoci spolužáka stezku označenou lanem. Jednou rukou se přidržuje lana, za druhou je veden spolužákem (s. 23). 


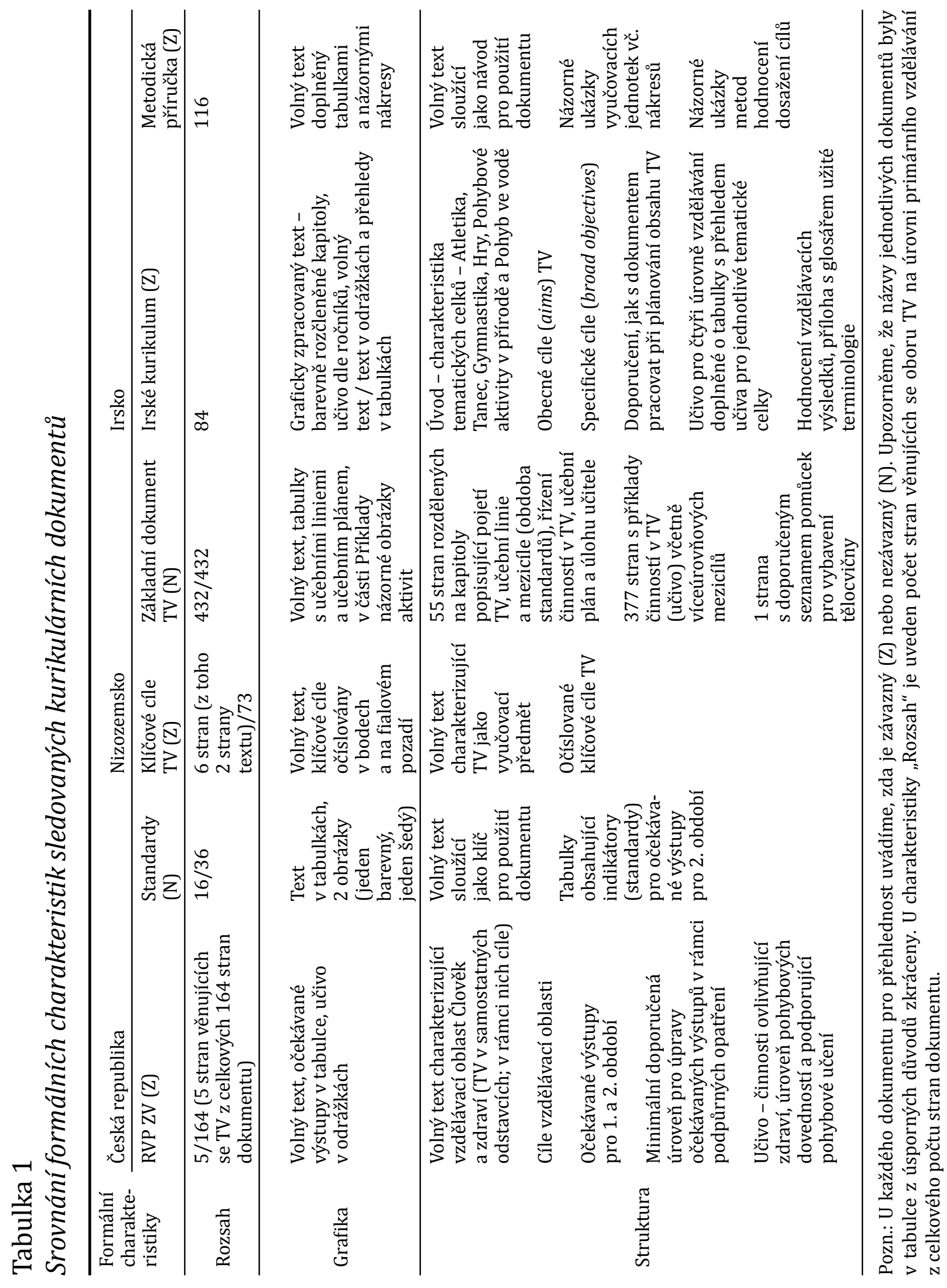


Také nizozemské kurikulum tuto oblast zdůrazňuje již v jednom z klíčových cílů. TV má pečovat o individuální rozvoj (žáci se mají seznámit s vlastními pohybovými schopnostmi a možnostmi jejich rozvíjení), ze sociálních vlastností je v úrovni cílů zmíněn respekt spoluhráče. Základní dokument poukazuje na význam pohybu v sociálním životě a TV vnímá jako prostředek pro sebeurčení. Konkrétně je např́iklad v dokumentu uvedeno, že „zvládání pohybových situací je spoluurčující pro důležité sociální vztahy, v rámci kterých jsou děti vnímány svým okolím“" (SLO ${ }^{6}, 2011$, s. 12).

Český vzdělávací program v charakteristice oboru TV zmiňuje účinnost pohybových činností na duševní a sociální pohodu jedince. Žákův prožitek z pohybu a z komunikace při něm má implikovat osvojení pohybových dovedností. Cílová oblast dokumentu se často dotýká kvalitních mezilidských vztahů, objevují se i pojmy jako etické a morální postoje. Je nutno poznamenat, že zmíněné cílové zaměření se vztahuje k celé vzdělávací oblasti Člověk a zdraví. Dokument nedefinuje, kterých $\mathrm{v}$ této části uvedených cílů má být dosaženo prostřednictvím vzdělávacího oboru Tělesná výchova a kterých má být dosaženo prostřednictvím vzdělávacího oboru Výchova ke zdraví, resp. jaké očekávané výstupy zmíněných vzdělávacích oborů podporují dosažení kterých cílů vzdělávací oblasti. V očekávaných výstupech, jež jsou v podstatě konkretizovanými cíli pro TV, se hovoří o jednání v duchu fair play, což je podpořeno též učivem $v$ rámci tematického celku Činnosti podporující pohybové učení.

\section{Rozvoj volních vlastností v tělesné výchově}

$\mathrm{V}$ cílech i obsahu irského dokumentu jsou zohledněny aspekty volního rozvoje žáků. Mají se snažit dosahovat zlepšení na individuální úrovni, učit se překonávat své vlastní možnosti a usilovat o cílevědomé plnění osobních výzev. $\mathrm{Z}$ obsahu dokumentu je také zřejmé, že je třeba u žáků pěstovat sebehodnocení.

Také RVP se zaměřuje na rozvoj volního úsilí, které má vést k individuálnímu zlepšení úrovně zdatnosti jak v oblasti cílů, tak také ve vzdělávacím obsahu. Nizozemské kurikulum o této oblasti nehovoří.

6 Nizozemský Institut pro rozvoj kurikula (SLO - Stichting Leerplan Ontwikkeling) 


\section{Učení na základě vzájemné spolupráce}

Téma vzájemného (colaborative) učení žáků se objevuje ve vzdělávacím obsahu irského dokumentu. Žáci mají být vedeni k využití spolupráce pro optimalizaci učení každého jednotlivce. Zcela konkrétně je navrhováno pobízení žáků $\mathrm{k}$ vzájemnému pozorování výkonu, který má být společně analyzován a hodnocen - např. si žáci mají všímat techniky správného provedení skoku přes překážky (s. 39); poradit spolužákovi, jakým způsobem je možné hodit dál, běžet rychleji či skočit výše (s. 51) apod. Zpětnou vazbu takového pozorování mají představovat návrhy žáků, jakým způsobem každý individuální výkon zlepšit. Učení v oblasti TV se tak má uskutečňovat také na základě aktivní interakce a vzájemného sdílení zkušeností a podnětů.

\section{Emoce jako součást tělesné výchovy}

Irský dokument zmiňuje „emocionální rozvoj“ jako jeden z hlavních cílů tělesné výchovy. Najdeme zde vyjádření v tom smyslu, že pozitivní emoce, které žák prožívá v TV, pomáhají zajistit kladný postoj k pohybové aktivitě a pohyb se tak přirozeně stává součástí způsobu života žáků. Téma emocí je zpracováno také v rovině specifických cílů, kde je ustanoveno, že TV má dát žákům pocítit prožitek z fyzické námahy a uspokojení z provedeného výkonu. Ve vzdělávacím obsahu jsou pak nabídnuty zejména příležitosti k ztvárnění emocí jiným než verbálním způsobem - nejčastěji tancem. Žáci se jeho prostřednictvím mají učit komunikaci a sebevyjádření, projevovat emoce a cvičit se také ve schopnosti interpretovat emoce z řeči těla spolužáka.

V českém RVP je podobně jako $\mathrm{v}$ irském dokumentu prožitek z pohybu posuzován jako prostředek k osvojování pohybových dovedností a zvládnuté dovednosti mají onen prožitek umocnit. V nizozemském dokumentu nejsou emoce takto explicitně řešeny.

\section{Význam her v kurikulu tělesné výchovy}

Ve všech dokumentech je téma pohybových a sportovních her zpracováno, ačkoliv v každém $\mathrm{z}$ nich je pojato svérázně. Zatímco nizozemské kurikulum se zaměřuje na výčet různých her, jejich organizaci a důsledný popis, irský dokument se (mimo výčtu her a vhodnosti jejich zařazení pro jednotlivé věkové úrovně) zamýšlí především nad výchovným působením her na osobnost a sociální vztahy žáka. Nizozemský dokument organizuje sportovní hry 
do dvou učebních linií (míčové hry a honičky ${ }^{7}$ ). Patrná je orientace na rozvoj herních dovedností a strategií - např. různých způsobů překonání brankáře nebo obehrání soupeře či kombinace výše zmíněných činností. Zmíněny jsou i některé modifikované verze známých sportovních her, např. cricketbal, hakobal nebo pilonbal. ${ }^{8}$

Irské kurikulum zařazuje hry jako samostatnou tematickou linii, která má být realizována v každé ze čtyř úrovní vzdělávání. Včlenění her do TV je odůvodněno jejich vlivem na rozvoj základních pohybových dovedností a také faktem, že hry poskytují množství příležitostí k sociální interakci. V dané oblasti se v dokumentu uplatňují tato hlediska: působení na osobnost žáka s důrazem zvláště na sociální aspekty, prožitek žáka, prohlubování pohybové znalosti, rozvíjení pohybových dovedností a uplatňování tvořivosti. Zřejmá je orientace především na osvojení herních strategií - zařazování průpravných cvičení, jež mají rozvíjet potřebné dovednosti a obratnost. Vyzdvižena je týmová práce, schopnost obrany, útoku a využití herního prostoru, uplatnění taktiky apod. Žákům má být také poskytnut prostor k vymýšlení her s přizpůsobenými pravidly. Podobně jako v nizozemském kurikulu je navrhováno zařazení modifikovaných verzí pohybových her.

Také český dokument neopomíjí pohybové hry. Problematika her je ve vzdělávacím obsahu zařazena do tematického celku Činnosti ovlivňující úroveň pohybových dovedností; pozornost je zde věnována jak sportovním hrám (respektování herních pravidel, herním kombinacím a herním činnostem jednotlivce), tak pohybovým hrám s různým zaměřením i hrám netradičním.

\section{Orientace na rozvoj a udržování zdraví}

Nizozemské kurikulum se problematiky zdraví dotýká pouze okrajově, nebot' touto problematikou se hlouběji zabývá vzdělávací oblast Orientace na sebe a okolní svět. Tělesná výchova má být pojímána především jako př́ležitost pro pohybovou rekreaci. V Irsku je výchova ke zdraví propojena především s předmětem Sociální, osobnostní a zdravotní výchova. Tato oblast je však i součástí projektované TV. Zdravotně orientovaná zdatnost (health-related

V originále tikspelen. Tik znamená plácnutí, klepnutí nebo cvaknutí, spelen znamená hra. Upozorňujeme, že pod názvem honičky dokument zmiňuje poněkud širší škálu her, než jaká se v českém prostředí pod tímto termínem obvykle skrývá.

8 Názvy her nemají český ekvivalent, proto je ponecháváme v původním jazyce. Pro jejich podrobný popis viz SLO (2011, s. 320-321, 362-364). 
fitness $^{9}$ ) je uvedena jako jeden ze základních cílů tělesné výchovy. Dále si má žák v této oblasti např osvojit některé relaxační techniky, které mu pomohou vyrovnávat se s náročnými fyzickými úkoly. Pohybové aktivity mají rozvíjet povědomí o vlastním těle - o správném napětí a držení těla či některých regeneračních cvičeních aj.

Nizozemský dokument přímo o zdraví pojednává jen ve velmi omezeném rozsahu. $\mathrm{V}$ úvodu je sice deklarováno, že „sport $\mathrm{v}$ důležité míře přispívá zdraví obyvatelstva" (SLO, 2011, s. 11), avšak vzhledem k tomu, že téma zdraví není nikde v dokumentu dále rozvíjeno, jedná se o víceméně obecné konstatování.

Charakteristika oboru, která otevírá část RVP ZV věnovanou vzdělávací oblasti Člověk a zdraví, vymezuje poznávání a praktickou podporu zdraví jako jednu z priorit základního vzdělávání. TV je samostatně charakterizována jako součást komplexnějšího vzdělávání žáků v problematice zdraví, která směřuje „na jedné straně k poznání vlastních pohybových možností a zájmů, na druhé straně k poznávání účinkủ konkrétních pohybových činností na tělesnou zdatnost, duševní a sociální pohodu“ (MŠMT, 2016, s. 91). Očekávané výstupy uvádějí, že žák by se měl podílet na realizaci pravidelného pohybového režimu, měl by do něj zařazovat $v$ případě potřeby korektivní cvičení a projevovat přiměřenou vůli $\mathrm{k}$ zlepšení úrovně své zdatnosti. $\mathrm{V}$ učivu je problematice zdraví věnován samostatný tematický celek s názvem Činnosti ovlivňující zdraví, který je zaměřen především na hygienu a správnou metodiku prováděných pohybových činností a rovněž hygienu cvičebního prostředí. Zároveň zařazuje první pomoc v podmínkách TV.

\section{Aspekty bezpečnosti v kurikulu tělesné výchovy}

Problematika bezpečnosti je průběžně zohledněna $v$ celém irském dokumentu (v cílové i obsahové části) především v podobě bezpečné organizace (zvedání, nošení a pokládání) cvičebního nářadí. Komplexně je však tato oblast pojednána zvláště v metodickém materiálu (NCCA, 1999b). Žáci si mají osvojit správné strečinkové techniky, zřetel je brán na přiměřené oblékání a nošení vhodné obuvi. Pro bezpečné fungování v TV je dále učiteli

\footnotetext{
Metodický dokument (NCCA, 1999b) rozlišuje mezi zdravotně orientovanou zdatností (health-related fitness), jejímž zorným úhlem je zdravotní stav, efektivní fungování těla a fyzická pohoda a která není specifikována pro konkrétní fyzické aktivity, a tělesnou zdatností (physical fitness), jež představuje různý rozsah zdatnosti vhodné pro individuální úroveň vývoje jedince ve sportovních aktivitách. Fyzická zdatnost není v analyzovaném dokumentu (NCCA, 1999a) explicitně vůbec zohledněna.
} 
doporučeno uvážit např. zdravotní stav žáka, fázi jeho vývoje či př́ipadné specifické potřeby apod.

Také obsah nizozemského kurikula se dotýká bezpečnosti. Zásadněji o ní pojednává kapitola, která se věnuje řízení pohybových činností. Je na učiteli, aby zvolil vhodnou formu participace žáků na př́pravě a průběhu aktivit tak, aby byla aktivita bezpečná.

Také v RVP ZV je jedním z očekávaných výstupů uplatnění hygienických a bezpečnostních zásad při pohybových činnostech, opomenuta není ani odpovídající reakce při úrazu spolužáka. $V$ učivu je dále uvedena příprava organismu před pohybovou činností, uklidnění po zátěži a napínací a protahovací cvičení nebo také organizace cvičebního prostoru, bezpečnost v prostorách šatny a umývárny a bezpečná manipulace s nářadím, náčiním a pomůckami.

Rozvoj celoživotní pohybové aktivity prostřednictvím tělesné výchovy

Téma celoživotní pohybové aktivity je důležitou složkou první části nizozemského dokumentu, která pojednává o pojetí TV. Autoři dokumentu zdůrazňují nutnost vedení žáků k pohybově aktivnímu a zdravému životnímu stylu, což je klíčovým cílem celé TV.

Také TV v Irsku má směřovat k celoživotní pohybové aktivitě, což je zřejmé $\mathrm{z}$ jednoho $\mathrm{z}$ cílů předmětu, ve kterém je zamýšleno zprostředkovávat „potěšení $\mathrm{z}$ fyzických aktivit a utvářet $\mathrm{k}$ nim pozitivní přístup, podporovat přínos celoživotnímu zdravému životnímu stylu a připravit žáka $\mathrm{k}$ aktivnímu a účelnému využívání volného času" (NCCA, 1999a, s. 10). Konkrétně je $v$ obsahu dokumentu navrhováno zacházet $v$ průběhu tělesné výchovy s pozitivními emocemi jako s faktorem vedoucím k celoživotnímu kladnému vztahu k pohybu.

V RVP ZV se snaha o rozvoj celoživotní pohybové aktivity projevuje již v charakteristice a vymezení cílového zaměření oboru Člověk a zdraví, ačkoliv $\mathrm{v}$ dokumentu není explicitně vyjádřena. Jeho autoři sice zmiňují, že žáci by měli být schopni „řadit do denního režimu pohybové činnosti pro uspokojování vlastních pohybových potřeb i zájmů, pro optimální rozvoj zdatnosti a výkonnosti, pro regeneraci sil a kompenzaci různého zatížení, pro podporu zdraví a ochranu života“" (MŠMT, 2016, s. 91), avšak již nezdůrazňují potřebu udržet tento postoj po celý zbytek života. Z částečné analýzy vzdělávacího oboru tělesná výchova pro 2. stupeň je snaha o rozvoj celoživotní 
pohybové aktivity patrná opět implicitně. Můžeme se však domnívat, že pokud autoři zamýšleli docílit aktivního životního stylu (např:: žák „aktivně vstupuje do organizace svého pohybového režimu ..." MŠMT, 2016, s. 98) žáků na konci 5. a 9. ročníku základní školy, považují tento cíl za dlouhodobý nejen z hlediska povinné školní docházky, ale i v budoucím životě žáků a dle našeho názoru by tak mělo být RVP ZV i chápáno.

Pohybový režim žáků je zmiňován také dále v očekávaných výstupech: (žák) „spojuje pravidelnou každodenní pohybovou činnost se zdravím a využívá nabízené př́ležitosti“ a „podílí se na realizaci pravidelného pohybového režimu" (MŠMT, 2016, s. 96). V učivu je snaha o rozvoj celoživotní pohybové aktivity včleněna do tematického celku Činnosti ovlivňující zdraví: význam pohybu pro zdraví - pohybový režim žáků, délka a intenzita pohybu (MŠMT, 2016, s. 97). Protože však pohybový režim ani délka a intenzita pohybu nejsou samy o sobě činnostmi, držíme se v naší analýze vyjádření v charakteristice vzdělávacího oboru a očekávaných výstupech. Osvojení kladného postoje k pohybové aktivitě je zde neodmyslitelně propojeno se zdravím, které je dominantním tématem $\mathrm{v}$ cílovém zaměření vzdělávací oblasti Člověk a zdraví.

\section{Extrakurikulární pohybové aktivity}

Tematika extrakurikulárních aktivit je vlastní pouze irskému kurikulu, v nizozemském i českém dokumentu zůstává tento motiv zcela bez povšimnutí. Extrakurikulárními aktivitami zde chápeme volitelné činnosti, které doplňují kurikulum, ale konají se mimo časový rozvrh výuky ve tř́dě. Tyto činnosti bývají dobrovolně organizované většinou učiteli nebo rodiči (NCCA, 1999a, s. 7). Tvůrci irského kurikula hovoří o extrakurikulárních pohybových aktivitách již v úvodu dokumentu, čímž chtějí podtrhnout myšlenku, že jedna vyučovací jednotka tělesné výchovy týdně (deklarovaná ministerstvem) nemůže pokrýt potřebu pravidelné fyzické aktivity dětí. Tyto činnosti mají především zprostředkovávat prožitek dětí či vytvářet a posilovat různé sociální vztahy.

\section{Zohlednění aspektů kultury a národního vědomí v kurikulu tělesné výchovy}

Cíl „účastnit se, rozvíjet znalost a oceňovat kulturní aktivity spjaté s pohybem" (NCCA, 1999a, s. 12) naznačuje, že motivy jako národní a kulturní vědomí mají v irském dokumentu výrazný charakter. V obsahu dokumentu jsou 
začleňovány pohybové aktivity, jež v Irsku stojí na silné tradici - např̀ irské lidové tance, gaelský fotbal či hurling (irský fotbal s pálkami). Je také doporučeno vést žáky k obeznámenosti s těmito tradicemi, např. že žáci mají znát původ lidového tance a úlohu, kterou tanec sehrává v různých kulturních kontextech. Dále má být utvářeno základní povědomí o místních, národních a mezinárodních sportovcích, událostech, organizacích a veřejných skupinách (gymnastických, atletických, herních, plaveckých aj.), žáci mají být vedeni k aktivní participaci v podobných organizacích na lokální úrovni. RVP ZV se v učivu konkrétně dotýká povědomí o olympijských ideálech a symbolech. Tato tematika je dále rozvíjena i v učivu druhého stupně, ve kterém je v rámci tematického celku Činnosti podporující pohybové učení zahrnuta „historie a současnost sportu - významné soutěže a sportovci, olympismus - olympijská charta" (MŠMT, 2016, s. 100). To dokládá zohlednění tématu také v českém kurikulu, avšak až ve vyšších ročnících. V nizozemském kurikulu není tato problematika rozvíjena.

\section{Význam životního prostředí v kurikulu tělesné výchovy}

Jak je patrné z irského dokumentu, na péči o životní prostředí je třeba dbát také při tělesné výchově. Tuto oblast zohledňuje především tematická linie Pohybové aktivity v př́rodě. Jak je uvedeno, žáky je třeba směřovat $\mathrm{k}$ tomu, aby oceňovali př́rodu a uvědomovali si potřebu vlastním přičiněním chránit životní prostředí. Péče o životní prostředí se má realizovat např. jako vhodná likvidace odpadků nebo opatrování všech živých organismů. Tvůrci českého ani nizozemského kurikula se tímto tématem ve svých dokumentech nezabývají.

\section{Teoretické znalosti v kurikulu}

V irském dokumentu je kladen důraz na to, aby žáci porozuměli konaným pohybovým aktivitám. Do každé z tematických linií je zařazena oblast Znalost a porozumění. Osvojování teoretických znalostí směřuje především $\mathrm{k}$ obeznámenosti s pravidly či schopností aplikovat určitou taktiku při hrách, $\mathrm{k}$ bezpečnému provádění pohybových aktivit a zacházení s nářadím, $\mathrm{k}$ tomu, aby byli žáci kompetentní řešit problémy a samostatně se rozhodovat. Do všech tematických linií je v poslední úrovni (5. a 6. ročník) zařazena informovanost o různých sportovních organizacích a klubech, žáci mají také získávat povědomí o sportovních událostech a sportovcích $\mathrm{v}$ rámci svého okolí, státu i mezinárodně. 
Podle nizozemského dokumentu by žáci měli být vedeni k získávání znalostí v oblasti pravidel sportovních i pohybových her a dále v oblasti taktických individuálních i skupinových činností (např. v zásadách obrany nebo útoku). Dokument též zdůrazňuje, že hodnota znalostí těchto principů má být vyvyšována nad hodnotu praktických dovedností. Autoři dokumentu hovoří o potřebě znalosti teorie pohybu. Znalosti se po žácích (i když nepřímo) vyžadují rovněž při řízení činností. Dokument předpokládá, že žáci musí nejen vědět jak, ale i umět posyktnout svým spolužákům dopomoc, vědět, jakým způsobem nachystat aktivitu nebo jakým způsobem modifikovat činnost tak, aby i nadále byla pro žáky srozumitelná, zábavná a aby se jich mohlo na činnosti podílet co nejvíce.

V RVP ZV jsou teoretické znalosti součástí tematických celků Činnosti ovlivňující zdraví a Činnosti podporující pohybové učení. V rámci učiva z prvního zmíněného tematického celku se mají žáci stát znalými zásad zdravého životního stylu, bezpečnosti, pohybového režimu a též by měli znát zásady přípravy před pohybovou činností, uklidnění po zátěži, napínacích a protahovacích cvičení, správného držení těla, správného zvedání zátěže a různých zdravotně zaměřených cvičení včetně průpravných, kompenzačních a relaxačních cvičení. Ačkoliv se (v některých př́ipadech) tedy jedná o činnosti, můžeme konstatovat, že je do značné míry nelze provádět bez teoretické znalosti jejich podstaty. Činnosti podporující pohybové učení zahrnují znalosti v oblasti základního tělocvičného názvosloví osvojovaných činností, smluvených povelů, signálů, základní organizace prostoru a činností ve známém (běžném) prostředí, zásad jednání a chování (fair play, olympijské ideály a symboly) a také v oblasti pravidel her, závodů a soutěží či znalosti základních pohybových testů a měření a posuzování pohybových dovedností (MŠMT, 2016, s. 98). Dodejme, že názvy tematických celků začínající slovem činnosti mohou být matoucí vzhledem k tomu, že nezahrnují pouze činnosti, ale rovněž znalosti a postoje. Tematický celek Činnosti ovlivňující úroveň pohybových dovedností zahrnuje pouze činnosti a dovednosti, avšak jejich zvládnutí je opět (implicitně) podmíněno zvládnutím příslušné teorie. ${ }^{10}$ S teorií pracují rovněž očekávané výstupy, které jsou na učivo navázány, např. „(žák) jedná v duchu fair play: dodržuje pravidla her a soutěží, pozná a označí zjevné přestupky proti pravidlům a adekvátně na ně reaguje; respektuje při pohybových činnostech opačné pohlaví" (MŠMT, 2016, s. 96).

10 Tematický celek zahrnuje napřs. skok do dálky či hod míčkem. Obě činnosti lze provádět spontánně bez výuky, avšak jsme přesvědčeni o tom, že pro jejich správné zvládnutí je potřeba si osvojit patřičnou dovednost, která musí vždy vycházet ze znalosti jejich teoretického pozadí. 
Sportovní odvětví v tělesné výchově

Tělesná výchova a sport nejsou v irském dokumentu posuzovány jako synonymní pojmy. Zatímco sport je postaven na konkurenci s jednotlivcem, skupinou či prostředím a zdůrazňuje potřebu výhry, tělesná výchova usiluje o všestranný rozvoj jedince (osobnostní, sociální a psychomotorický), směřuje k individuálnímu zdokonalení, nikoli ke snaze být co nejlepší. Zařazení sportovních aktivit (běh, hod, gymnastika, plavání apod.) v průběhu vzdělávacího obsahu by tedy dle těchto slov mělo být míněno jako prostředek rozvoje pohybových dovedností. Podobně je tomu, co se týče zařazení sportů, v nizozemském dokumentu.

V českém RVP můžeme problematiku sportovních odvětví identifikovat v činnostech ovlivňujících úroveň pohybových dovedností, konkrétně pak v gymnastice, atletice, sportovních hrách, plavání, lyžování a bruslení. Ve všech př́ipadech se jedná o základní dovednosti a činnosti. $V$ prrípadě sportovních her dokument nejmenuje konkrétní hry, avšak nabízí pohybové činnosti, které jsou nezbytným krokem ke zvládnutí sportovních her.

\section{Problematika výkonu v tělesné výchově}

Irský dokument v cílové části pojímá výkon ve smyslu individuální výzvy, které chce žák dosáhnout. Význam je kladen zvláště na prožitek, který je zde zjevně chápán jako významnější nežli úsilí být co nejlepší. Vzdělávací obsah dokumentu nicméně není s těmito formulacemi zcela ve shodě. Dá se říci, že uvedené př́íklady indikují výkon, kterého mají žáci dosáhnout - např v tematickém celku Atletika mají být žáci určitého věku schopni přeskočit přes překážku vysokou alespoň $30 \mathrm{~cm}$ (s. 26) apod.

Nizozemský dokument ve svém vzdělávacím obsahu ani cílovém zaměření není na výkon orientován. $Z$ hlediska jeho měření tak klade důraz na srovnávání žáků se sebou samými a upozorňuje na problematiku vzájemného srovnávání žáků, které může být ze sociálního hlediska nevhodné.

Český dokument hovoří o výkonu v očekávaných výstupech v souvislosti se zvyšováním úrovně zdatnosti žáků a uplatňováním kondičně zaměřených činností. O rozvoji optimální výkonnosti a zdatnosti se zmiňuje rovněž charakteristika oboru TV. Obsah dokumentu ovšem orientaci na výkon nijak nevyvyšuje. 


\section{Závěr}

Naším záměrem bylo analyzovat a porovnat projektovaná kurikula TV Irska, Nizozemska a České republiky. Zajímalo nás, jakým způsobem se můžeme výsledky této analýzy poučit a co může přinést pro český kontext. $\mathrm{K}$ analýze jsme přistupovali s povědomím určitých témat, která jsme převzali z jiných výzkumů - to proto, aby bylo možné provést komparaci dokumentů. Tato témata měla být také nástrojem, podle něhož jsme zamýšleli posuzovat kongruenci uvnitř každého z projektovaných kurikul. Během studia se vynořila další zajímavá témata, což nás utvrdilo v názoru, že podobnou analýzu nelze provádět podle určité uzavřené sady kategorií, nebot' bychom se připravili o cenná a inspirativní data. Připomeňme, že ve výzkumu bylo pracováno také s kontextuálními faktory, avšak pro omezený rozsah časopisecké studie zde zmíněny nejsou. Čtenáře pro hlubší porozumění odkazujeme na jiné práce autorů (Habrdlová, 2014; Lupač, 2016).

Výsledky provedené komparace bychom mohli shrnout do následujících tezí:

V každém z dokumentů zaznamenáváme rozdílné pojetí cílů pro TV. Zatímco irský dokument předepisuje cíle obecné, které jsou dále konkretizovány ve formě specifických cílů, jež se promítají do několika dimenzí žákova vývoje, nizozemské kurikulum projektuje pro TV pouze dva značně obecné cíle. České RVP stanovuje cíle jednak v podobě klíčových kompetencí (tedy nikoli normy, které dosáhne v určitém čase každý z žáků, ale úrovně, jež je pro žáka individuálně dosažitelná a jež má být mezistupněm dalšího vzdělávání), jednak ve formě cílů oboru TV. Ty jsou předepsány pro celou vzdělávací oblast Člověk a zdraví, tj. i pro obor Výchova ke zdraví. Na tyto cíle navazují očekávané výstupy. Dá se říci, že všechny tři dokumenty akcentují individualizaci cílů - má být usilováno o osobní maximální úroveň každého jedince v závislosti na jeho individuálních možnostech. Všechny sledované dokumenty také vymezují cíle (nikoli nezbytně v tomto označení) jednak pro úroveň rozvoje žáka, jednak ve formě konkrétního učiva, které si má žák osvojit.

Projektovaný obsah učiva se $\mathrm{v}$ mnoha oblastech do značné míry shoduje, zřejmá je však rozdílná úroveň významnosti, jež je jednotlivým obsahům přisuzována. Ve všech kurikulárních dokumentech jde spíše o proměnu celkové zkušenosti žáka ve škole, nikoli o oborově specifické otázky tělesné výchovy. S tím souvisí např. odklon od jednostranné orientace na výkon v českém a irském dokumentu - tato oblast je nahrazována důrazem na osobní 
prožitek, uspokojení a seberealizaci žáků. Ve všech dokumentech zaujímají sportovní aktivity spíše vedlejší úlohu; jak je avizováno, je třeba rozvíjet zvláště pohybové dovednosti. Také pojem zdatnost je nahlížen ve všech případech v zásadě shodně - prostředkem jejího rozvoje také není dosažený výkon (tzv. výkonově orientovaná zdatnost), ale zdatnost je považována za nezbytnou součást lidského zdraví (tzv. zdravotně orientovaná zdatnost). U všech porovnávaných zemí je patrný požadavek komplexnosti působení na žáka, na jeho rozvoj v oblasti kognitivní, sociální a osobnostní, volní, u českých a irských dokumentů také v oblasti emocionální.

Uvážíme-li vnitřní kongruenci dokumentů, jsou cíle irského dokumentu provázané se vzdělávacím obsahem (tzn. každé téma, uvedené jako cíl TV, se promítá také v obsahu). Učební obsah dále uvádí konkrétní návrhy činností, jimiž je možné stanovených cílů dosahovat. $V$ př́ípadě nizozemského kurikula jsou cíle natolik obecné, že je obtížné sledovat jejich promítnutí do vzdělávacího obsahu i kontrolovat jejich dosažitelnost (viz námi dále v textu zmiňované další kvality kurikula, jako je srozumitelnost a podrobnost). Cíle předepsané pro TV v RVP ZV se jednoznačně orientují na zdraví, jsou tedy nekongruentní se vzdělávacím obsahem, který není tak vyhraněný, protože zdravotní pojetí je významně vyvažováno pojetím pohybovým.

Odlišné zpracování sledovaných dokumentů nás přimělo pozorovat vedle kongruence obsahu také technickou podobu dokumentů, tedy kongruenci formální. Shledali jsme, že ve všech sledovaných případech je patrný překryv témat vždy v návaznosti na předchozí úroveň. To znamená, že žák se s pojmy a činnostmi setkává opakovaně v jednotlivých vzdělávacích úrovních a dochází tedy $\mathrm{k}$ postupné kumulaci vzdělávacího obsahu. RVP však není $\mathrm{v}$ části vymezené pro vzdělávací obor Tělesná výchova po formální stránce zcela kongruentní, nebot' vymezuje vzdělávací obsah pro první stupeň jako obecně definované očekávané výstupy a dále učivo strukturované jako Činnosti ovlivňující zdraví, Činnosti ovlivňující úroveň pohybových dovedností, Činnosti podporující pohybové učení, avšak pro druhý stupeň je organizace odlišná - očekávaným výstupům jsou nadřazeny koncepty Činnosti ovlivňující zdraví, Činnosti ovlivňující úroveň pohybových dovedností, Činnosti podporující pohybové učení (viz MŠMT, 2016, 79-81).

Míra podrobnosti ${ }^{11}$ a srozumitelnosti pro učitele jako další kvality kurikula je vysoká v irském a nizozemském vzdělávacím obsahu, což je podpořeno zcela

11 Dvořák (2012, s. 32) hovoří o šířce a hloubce. 
konkrétními návrhy činností, v případě Irska také provázaností s obsáhlým metodickým materiálem (NCCA, 1999b), jenž předkládá metodické návrhy a možnosti realizace témat obsažených v dokumentu. U RVP ZV bychom mohli vyzdvihnout stručnost a úspornost jazykového vyjádření, vedeme-li v patrnosti, že jde o rámec, se kterým se dále pracuje při tvorbě školních vzdělávacích programů.

V návaznosti na výše popsané můžeme formulovat několik doporučení pro možné směřování příštích revizí českého kurikula. Zásadním nedostatkem tělesné výchovy projektované $v$ RVP ZV je neprovázanost (značně abstraktních) vzdělávacích cílů a vzdělávacího obsahu. Cíle, jak jsme uvedli výše, akcentují především podporu zdraví. Má-li tělesná výchova směřovat k podpoře zdraví ${ }^{12}$ jako základní hodnotě vzdělávání v tělesné výchově, je třeba tyto cíle promítnout také do vzdělávacího obsahu, tedy očekávaných výstupů a učiva. $S$ touto skutečností úzce souvisí fakt, že RVP ZV je, na rozdíl od dalších sledovaných dokumentů, charakteristický orientací na kompetence potřebné v budoucím životě žáka. Podobně jako Young $(2010$, s. 10) se domníváme, že je-li kurikulum orientováno na rozvoj kompetencí, některé podstatné vzdělávací cíle (a také př́ležitosti k progresi) se mohou ztrácet ${ }^{13}$ (srov. Štech, 2009). Důraz na kompetence, jak se ve srovnání s dalšími dvěma dokumenty zdá, opomíjí oborová specifika. Jsou-li cíle formulovány v podobě kompetencí, je také velmi obtížná jejich evaluace a tím sledování kongruence mezi jednotlivými formami kurikula. Provázanosti projektované formy kurikula, která byla předmětem našeho bádání, by jistě napomohlo definování více specifických cílů včetně možných způsobů evaluace dosažení těchto cílů (srov. Píšová et al., 2011, s. 281). Takto bychom posílili kongruenci projektovaného kurikula - počátečního faktoru kvalitního vzdělávání v tělesné výchově.

\section{Literatura}

Annerstedt, C. (2008). Physical education in Scandinavia with a focus on Sweden: A comparative perspective. Journal Physical Education and Sport Pedagogy, 13(4), 303-318.

Bereday, G. (1964). Comparative method in education. New York: Holt, Rinehart and Winston.

Dvořák, D. (2012). Od osnov k vzdělávacím standardům. Praha: Pedagogická fakulta Karlovy univerzity.

12 O čemž se v současné době vede diskuze a objevuje se spíše úvaha o směřování k pohybové gramotnosti (viz Vašíčková, 2016).

13 Kompetence jsou během vzdělávání u žáka rozvíjeny, žákova vybavenost kompetencemi v jeho dalším životě se však obtížně hodnotí. 
Dvořák, D., Starý, K., \& Urbánek, P. (2015). Malá škola po pěti letech: proměny školy v době reformy. Pedagogická orientace, 25(1), 9-31.

Glaser, B. G. (2004). Remodeling grounded theory. Forum: Qualitative Social Research, 5(2), Article 4.

Glaser, B. G., \& Strauss, A. L. (1967). The discovery of grounded theory: Strategies for qualitative research. Chicago: Aldine.

Habrdlová, M. (2014). Projektované kurikulum tělesné výchovy pro primární vzdělávání v Irsku (Diplomová práce). Brno: Masarykova univerzita.

Holmes, B. (1981). Comparative education: Some consideration of method. London: Allen and Unwin.

Horváthová, M. (2015). Review study OECD Dutch curriculum: „\#onderwijs2032“. Dostupné $\mathrm{z}$ http://onsonderwijs2032.nl/wp-content/uploads/2015/09/OECD-Paper-4-BASICPRINCIPLES-FOR-CURRICULUM-REDESIGN.pdf

Janík, T. (2013). Od reformy kurikula k produktivní kultuře vyučování a učení. Pedagogická orientace, 23(5), 634-663.

Janík, T., Maňák, J., Knecht, P., \& Němec, J. (2010). Proměny kurikula současné české školy: vize a realita. Orbis scholae, 4(3), 9-35.

Janík, T., Najvar, P., \& Solnička, D. (2011). Od idejí k implementaci: kurikulární reforma v rozhovorech s řediteli (nepilotních) gymnázií. Orbis scholae, 5(3), 63-85.

Jin, A. (2013). Physical education curriculum reform in China: A perspective from physical education teachers. Physical Education and Sport Pedagogy, 18(1), 15-27.

Kougioumtzis, K. (2014). The experienced physical education curriculum: A comparative study of primary and lower secondary school pupils in Sweden and South Africa. Göteborg: University of Gothenburg.

Kuhn, J. (2011). Kurikulární reforma v poločase. Pedagogická orientace, 21(4), 480-486.

Kuřina, F. (2014). Kompetence a školní praxe. Rozpaky oborového didaktika nad kurikulární reformou. Pedagogická orientace, 24(3), 433-442.

Lupač, M. (2016). Obsahová analýza kurikulárních dokumentů tělesné výchovy v Nizozemsku z hlediska vybraných faktorů kvality projektovaného kurikula: komparace s RVP ZV. Studia sportiva, 10(1), 15-32.

Manzon, M. (2007). Comparing places. In M. Bray, B. Adamson, \& M. Mason (Eds.), Comparative education research: Approaches and methods (s. 85-123). Hong Kong: Comparative Education Research Centre, The University of Hong Kong.

Maňák, J., \& Janík, T. (2009). Kurikulum. In J. Průcha (Ed.), Pedagogická encyklopedie (s. 117-122). Praha: Portál.

MŠMT. (2013). Standardy pro základní vzdělávání. Tělesná výchova (zdravotní tělesná výchova). Dostupné z http://digifolio.rvp.cz/artefact/file/download.php?file $=67504 \& v i e w=9832$

MŠMT. (2016). Rámcový vzdělávací program pro základní vzdělávání. Praha: MŠMT.

Naul, R. (2003). Koncepce školní tělesné výchovy v Evropě. Česká kinantropologie, 7(1), 39-53.

Naul, R. (2011). Conceptual diversity and future directions of physical education in the global context. Japanese Journal of Sport Education Studies, 30(2), 39-50.

NCCA. (1999a). Physical education primary school curriculum. Dostupné z http://www. curriculumonline.ie/getmedia/ca8a385c-5455-42b6-9f1c-88390be91afc/PSEC05_ Physical-Education_Curriculum.pdf 
NCCA. (1999b). Physicaleducation teacher guideliness. Dostupnéz http://www.curriculumonline. ie/getmedia/2ca06265-2e75-4cc1-8174-661a877728d4/PE_Guidelines_english.pdf

OCW. (2016). Ons onderwijs2032 Eindadvies. Dostupné z http://onsonderwijs2032.nl/wpcontent/uploads/2016/01/Ons-Onderwijs2032-Eindadvies-januari-2016.pdf

Píšová, M., Kostková, K., Janík, T., Doulík, P., Hajdušková, L., Knecht, P., ... \& Vlček, P. (2011). Kurikulární reforma na gymnáziích: prípadové studie tvorby kurikula. Výzkumná zpráva. Praha: Výzkumný ústav pedagogický.

Průcha, J. (2015). Srovnávací pedagogika: mezinárodní komparace vzdělávacích systémů. Praha: Portál.

Průcha, J., Walterová, E., \& Mareš, J. (2001). Pedagogický slovník. Praha: Portál.

Richter, C. (2006). Konzepte für den Schulsport in Europa: Bewegung, Sport und Gesundheit (Disertační práce). Aachen: Mayer \& Mayer.

Rossi, T., Tinning, R., McCuaig, L., Sirna, K., \& Hunter, L. (2009). With the best of intentions: A critical discourse analysis of physical education curriculum materials. Journal of Teaching in Physical Education, 28(1), 75-89.

SLO. (2006). Kerndoelen Primair Onderwijs. Dostupné z http://www.slo.nl/primair/kerndoelen/ Kerndoelenboekje.pdf/download

SLO. (2011). Basis dolment Bewegingsonderwijsvoorhet Basisonderwijs. Den Haag: Delta Hage.

Squires, D. (2012). Curriculum alignment research suggests that alignment can improve student achievement. The Clearing House: A Journal of Educational Strategies, Issues and Ideas, 85(4), 129-135.

Strauss, A. L., \& Corbin, J. (1999). Základy kvalitativního výzkumu: postupy a techniky metody zakotvené teorie. Boskovice: Albert.

Šíp, R. (2014). Problematické aspekty současné pedagogiky z pohledu pedagogické filozofie: vztah praxe a teorie a potlačení somatické dimenze pedagogických procesů (Habilitační práce). Brno: Masarykova Univerzita.

Štech, S. (2009). Zřetel k učivu jako problém dvou modelů kurikula. Pedagogika, 59(2), 105-116.

Švaříček, R., \& Šed'ová, K., et al. (2007). Kvalitativní výzkum v pedagogických vědách. Praha: Portál.

Vašíčková, J. (2016). Pohybová gramotnost v České republice. Olomouc: Univerzita Palackého.

Vlček, P. (2015). Srovnávací výzkum v pedagogice: některé úvahy o metodologii problémového př́stupu. Pedagogická orientace, 25(3), 394-412.

Vlček, P., \& Janík, T. (2010). Školské reformy a tvorba kurikula tělesné výchovy $v$ České republice, Spolkové republice Německo a Spojených státech amerických: pedagogický výzkum v teorii a praxi. Brno: Paido.

Vlček, P., \& Mužík, V. (2012). Soulad mezi projektovaným a realizovaným kurikulem jako faktor kvality vzdělávání v tělesné výchově. Česká kinantropologie, 16(1), 31-46.

Walterová, E. (2006). Srovnávací pedagogika: vývoj a proměny v globálním kontextu. Praha: Pedagogická fakulta Karlovy univerzity.

Young, M. (2010). Alternative educational futures for a knowledge society. European Educational Research Journal, 9(1), 1-12.

Zhu, X., Ennis, C. D., \& Chen, A. (2011). Implementation challenges for a constructivist physical education curriculum. Physical Education and Sport Pedagogy, 16(1), 83-99. 


\title{
Autoři
}

Mgr. Martina Habrdlová, Masarykova univerzita, Pedagogická fakulta, Katedra tělesné výchovy a výchovy ke zdraví, Poříčí 31, 60300 Brno, e-mail: 322247@mail.muni.cz

Mgr. Michal Lupač, Masarykova univerzita, Pedagogická fakulta, Katedra tělesné výchovy a výchovy ke zdraví, Poříćí 31, 60300 Brno, e-mail: lupac@mail.muni.cz

PhDr. Mgr. Petr Vlček, Ph.D., Masarykova univerzita, Pedagogická fakulta, Katedra tělesné výchovy a výchovy ke zdraví, Poříćí 31, 60300 Brno, e-mail: vlcek@ped.muni.cz

\section{Comparison of the PE content of the chosen primary curriculum documents in the Czech Republic, the Republic of Ireland and the Netherlands}

\begin{abstract}
This study deals with the comparison of current physical education curricular documents (especially educational programmes) of the Czech Republic, the Republic of Ireland and the Netherlands for primary education. In the first part the study introduces the context of the research problem followed by literature review and research goals specification. On this basis, the methodology of the curricular documents comparison is described. The following section provides the key results of the investigation carried out which were interpreted in relation to the Czech curricular revisions. As fundamental the authors find that the goals and the educational content of PE in the Czech curriculum is not congruent and comprehensible. On the basis of the findings some recommendations for future Framework educational programmes revisions are outlined.
\end{abstract}

Keywords: curriculum, educational programmes, physical education, comparison, the Republic of Ireland, the Netherlands, the Czech Republic

Obst, O. (2017). Obecná didaktika. Olomouc: UP.

Studijní opora je určena všem kategoriím učitelů sekundárních škol, kteří se na svoji profesi připravují ve všech formách studia na PdF UP v Olomouci. Autor preferuje model ID a konstruktivistické pojetí výuky, které je i základní filozofií rámcových vzdělávacích programů. V první a druhé kapitole jsou vysvětleny základní pojmy obecné didaktiky, pozornost je věnována i problematice výukových cílů. Výklad teoretických pojmů je doplněn příklady z praxe a třetí kapitola sama naznačuje možnosti uplatnění základních didaktických kategorií přímo ve výuce, obsahuje i témata, kterými se obecná didaktika tradičně nezabývá (kázeň ve výuce, humor ve výuce, klima třídy aj.). Čtvrtá kapitola je věnována stylu práce učitele, problematice jeho kompetencí, sebereflexi a sebezdokonalování učitele. 